\title{
Introduction of standardization of powered roof supports to increase production efficiency of Polska Grupa Górnicza S.A.
}

\begin{abstract}
Text The introduction of the standardization of a powered roof support is a key point in increasing production efficiency in the mines of Polska Grupa Górnicza S.A. The introduced changes will increase the safety of the miners and affect the economic result associated with the exploitation of coal. The purpose of introducing this standardization is to systematize the construction solutions of roof supports in terms of power and control hydraulics, focusing on all technical conditions that powered roof supports operating in underground mining facilities must meet (including mining tremors). This article presents the method of standardizing the powered roof supports that are produced, modernized, and renovated by Zakład Remontowo-Produkcyjny within Polska Grupa Górnicza S.A.
\end{abstract}

Key words: standardization, powered roof support, increased production efficiency

\section{INTRODUCTION}

Polska Grupa Górnicza S.A. (PGG) currently conducts mining work in about 50 longwalls in 8 mines. The average working depth reaches 710 meters. The natural hazards mainly include tremors, methane, and water. The operation is carried out only by longwall systems based on caving, using a combine harvester as a mining machine $[1,2]$. The thickness of the longwalls reaches about $2.6 \mathrm{~m}$. The annual production of PGG is about 30 million tons ( 82 thousand tons a day on average). Supporting and shielding systems equipped with supporting legs are mainly used. Over $60 \%$ of the exploitation of longwalls are carried out under conditions of tremor hazards. The degree of the threat of rock mass impact assessed on the basis of the $n_{\mathrm{tz}}$ coefficient ranges from 1.1 to 1.4 [1-3], whereas the $g$ indicator must stay within a range of 0.7 to over 1.2 to ensure the adequate maintenance of the roof described, which indicates that there is no optimized load-bearing capacity of the roof supports to the actual needs. Between two and five types of roof supports are used in one longwall, with the basic supply pressure reaching $25 \mathrm{MPa}$. The majority of the control systems are based on RB, with pilot control being applied much less often. The electro-control has not been applied yet. In some cases, electronic pressure monitoring systems are used. There are about 200 types of roof supports registered. They are mainly supporting and shielding structures with various leg parameters (cylinder diameters, lengths). An exemplary list of the used supports of the selected PGG mines is presented in Table 1.

A considerable number of longwalls are equipped with several types of sections that often differ in their geometry and load-bearing capacity. There are cases when the original elements are replaced with substitutes of dubious quality for different reasons. (financial, organizational, no availability of original spare parts). This makes it difficult to exploit and maintain the support to a significant extent and to determine the real causes of a malfunction. It is worth noting 
that the majority of powered roof supports operating in PGG's mines have been used for twenty years on average, and there are still supports that were introduced almost thirty years ago. Table 2 presents the number of sections operating in PGG, depending on the year of production.

Table 1

Exemplary list of used supports of selected PGG mines

\begin{tabular}{|l|c|}
\hline \multicolumn{1}{|c|}{ Type of powered roof support } & $\begin{array}{c}\text { Range of working } \\
\text { height of section } \\
\text { [m] }\end{array}$ \\
\hline Fazos 08/22 2x2690 & $1.0-2.1$ \\
\hline Fazos 08/22 2x2690-1 & $1.0-2.1$ \\
\hline KW 09/26 POz/ZRP w. III & $1.5-2.5$ \\
\hline KW 09/26 POz/ZRP/BSN w. III & $1.5-2.5$ \\
\hline Fazos 16/37 POz & $1.7-3.7$ \\
\hline Fazos 16/37 POz/BSN & $1.7-3.7$ \\
\hline KW 16/37 POz/ZRP & $1.8-3.6$ \\
\hline KW 16/37 POz/ZRP/BSN & $1.8-3.6$ \\
\hline Tagor 18/36 POz & $2.0-3.5$ \\
\hline Tagor 18/36 POz/S & $2.0-3.5$ \\
\hline Fazos 19/35 OzM5 & $1.9-3.4$ \\
\hline KW 20/36 POz/ZRP & $2.2-3.5$ \\
\hline KW 20/36 POz/ZRP/BSN & $2.2-3.5$ \\
\hline KW 20/36 POzW1/ZRP & $2.2-3.5$ \\
\hline KW 14/28 POz/ZRP & $1.5-2.7$ \\
\hline KW 14/28 POz/ZRP/BSN & $1.5-2.7$ \\
\hline Fazos 15/31 OzM5 & $1.7-3.0$ \\
\hline BW 20/36 OzMR2 & $2.5-3.5$ \\
\hline BW 17/43POz & $2.0-3.6$ \\
\hline
\end{tabular}

Table 2

List of number of power roof supports in PGG with breakdown per year of production

\begin{tabular}{|l|c|}
\hline \multicolumn{1}{|c|}{ Year of production } & Number of supports [pcs.] \\
\hline By 1980 & 434 \\
\hline $1981-2000$ & 6620 \\
\hline $2001-2016$ & 8056 \\
\hline
\end{tabular}

The variety of the types and technical solutions complicates the maintenance and the possibility of using working roof supports in other longwalls.
Regardless of the way they are placed on the market, all roof supports are subject to additional assessments of the load-bearing capacity often conducted by a scientific research unit in the case of usage under conditions of rock mass impact. Table 3 shows the number of support sections in PGG, depending on the method of placing on the market.

Table 3

\section{Number of supports in PGG depending on method of placing on market}

\begin{tabular}{|l|c|l|}
\hline $\begin{array}{c}\text { Year of } \\
\text { production }\end{array}$ & $\begin{array}{c}\text { Number of } \\
\text { supports [pcs.] }\end{array}$ & $\begin{array}{c}\text { Legal basis for market } \\
\text { introduction }\end{array}$ \\
\hline By 2004 & 7443 & $\begin{array}{l}\text { admission issued by the } \\
\text { President of the Higher } \\
\text { Mining Office }\end{array}$ \\
\hline Since 2004 & 7667 & $\begin{array}{l}\text { EC type examination } \\
\text { certificate }\end{array}$ \\
\hline
\end{tabular}

Currently, roof supports are introduced on the market in compliance with the security requirements set out in the European Parliament's Machinery Directive [4] and harmonized Polish standards PN-EN 1804 series [5-7]. Due to the fact that the standards of the PN-EN 1804 series include a record excluding their validity in the case of rock mass hazard, the support should be adapted by "allowing" it to take over dynamic loads under the Regulation of the Minister of Energy of November 23, 2016, [8] on the detailed requirements for running underground mining facilities (effective July 1, 2017).

In contrast to the previous regulation of the Minister of Economy of June 28, 2002, on the Occupational Health and Safety, Traffic, and Specialized Fire Protection in Underground Mines (valid until July 1, 2017), The new regulation of the Minister of Energy does not recognize the requirement assessment of the possibility of the cooperation between different types of supports in one longwall. This means that, in light of the currently binding legal acts, the assessment of the possibility of the cooperation of several roof supports in one longwall is optional and rests solely on the manager of the mining department, who may support the opinion of appointed teams of consultants. The use of several types of powered roof supports in one longwall leads to a number of issues. Analysis [9] shows that an important stage in the process of adapting the support to the prevailing geological and min- 
ing conditions in a given excavation is the selection of its support system [10,11], strictly resulting from the assessment of roof maintenance index $g$. Therefore, for the safe and effective operation of a longwall complex, further cooperation with the Central Mining Institute is recommended. Roof index $g$ should be included in the process of selecting the support for the actual operating conditions. This paper presents the standardization process of powered roof supports (both renovated and produced) as a part of PGG S.A.

\section{RULES FOR OPERATION OF ROOF SUPPORTS}

The prospect of meeting the requirements of the market enforces the decisive rationalization of the costs of coal mining through the improvement of the organization, employment, and degree of use of the machinery, which should lead to an increase in daily output from the wall. Such a tendency should be maintained with deteriorating mining conditions and strong external competition. The benefits of the above process include ensuring the operation of the longwall system as well as the functionality while minimizing the purchase and operation costs.

The standardization was initiated at Zakład Remontowo-Produkcyjny, which has been a branch of Polska Grupa Górnicza for ten years. Cooperation with scientific and research units (including the Main Mining Institute and the KOMAG Institute of Mining Technology) was indispensable. The increasingly difficult mining and geological conditions contribute to the increase in the risk of rock mass shocks, precisely imposing the technical conditions that the powered roof support must meet and indicating the need to standardize the support structure.

Based on an analysis of this state and the anticipated needs for the coming years, the most important directions of action in the field of standardization of the construction of powered roof supports were set out [12]. Determining the basic directions of the standardization of roof support construction has allowed us to optimize roof support management, taking full advantage of the existing powered roof supports and the production potential of Zakład RemontowoProdukcyjny.
The standardization included three main components of a roof support:

- construction of the section,

- power hydraulics,

- control hydraulics.

For this concept, actions have been taken in the following areas:

1) construction of section:

- adjusting the working height of the powered roof support to the current needs;

- increasing the load-bearing capacity of the roof support while strengthening the structures of the roof supports owned by PGG;

- introduction of proprietary procedures - Zakład Remontowo-Produkcyjny has tightened the safety coefficients imposed by standards on the load on stand seats (introduction of Coefficient 2 instead of the required 1.5) [13];

- introduction of facilities to the roof support at the request of representatives of the mines that facilitate operation and repair;

- introduction and application of the same auxiliary cylinders for different types of roof supports (longwall face shield actuator, transition cover, side shield correction actuator).

2) power hydraulics:

- legs were limited to one type, with a two-telescopic structure with a bottom valve, with first-stage diameters:

- $0.21 \mathrm{~m}$ - KW-08/22-POz/ZRP, KW-09/26-POz/ ZRP,

- 0.25 m - KW-14/28-POz/ZRP, KW-18/34-POz/ ZRP, KW-20/36-POz/ZRP, KW-17/43-POz/ZRP,

- $0.32 \mathrm{~m}$ - KW-16/37-POz/ZRP;

- hydraulic legs are equipped with ZRP connections:

- size I: DN12/DN12 - min. flows for $60 \mathrm{MPa}$ $450 \mathrm{l} / \mathrm{min}$ at $15 \%$ flow losses for a $0.21 \mathrm{~m}$ diameter,

- size II: DN19 / DN12 - min. flows for $60 \mathrm{MPa}$ $650 \mathrm{l} / \mathrm{min}$ with flow losses of $15 \%$ for a leg with a diameter of $0.25 \mathrm{~m}$ and $0.32 \mathrm{~m}$.

3) control hydraulics - introduction of a procedure to select the protection of the powered roof support sections against dynamic overloads based on the method of determining the resultant flow of the system: connection-valve (Fig. 1). For this purpose, Zakład Remontowo-Produkcyjny has developed detailed requirements for the purchase of pressure/relief valves. 


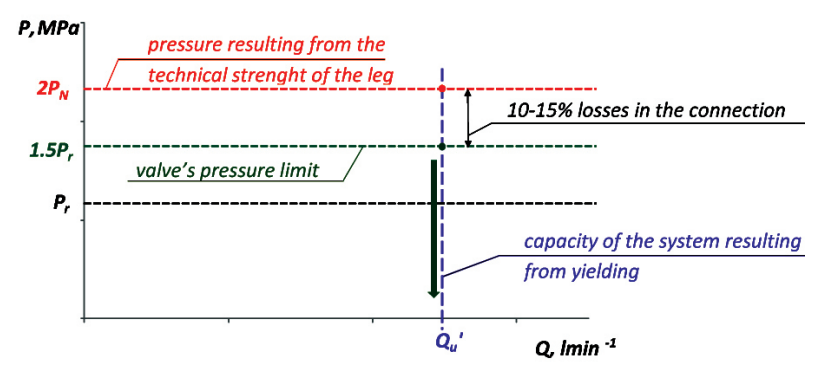

Fig. 1. Method of determining resultant flow of connection-valve system

\section{DIRECTION OF STANDARDIZATION}

The section of the powered roof support in accordance with machinery directive [2] is a machine consisting of a structure as well as power and control hydraulics and, as a whole, should be placed on the market and used unchanged throughout the life of the machine. This is extremely important for safety, technical, and cost reasons; any deviation from the above-mentioned principles results in a radical increase in the risk of failure, which translates into a deterioration in work safety. A derivative issue that is also beneficial is the unification of the demand for purchasing elements, the simplification of maintenance works, and all kinds of repairs.

To meet these requirements, PGG S.A. has decided to secure its immediate needs in the field of longwall development and powered roof supports acquired based on its own documentation, taking into account the standardization and aggregation of the purchase system. An analysis was based on the scope of work of the roof support sections through 2020 (Tab. 4) carried out in order to assess these needs.

\section{Table 4}

List of needs in area of powered supports sections for 2018-2020

\begin{tabular}{|c|c|}
\hline Scope of work & Number of sections \\
\hline $1.0-2.5$ & 178 \\
\hline $1.8-3.3$ & 425 \\
\hline $2.0-4.0$ & 318 \\
\hline $2.6-4.6$ & 121 \\
\hline
\end{tabular}

Having regard to the above needs and optimizing the working ranges for newly designed powered roof supports in Zakład Remontowo-Produkcyjny, design work was undertaken to develop new types of roof supports. Three basic types of support and shielding systems based on a pitch of $1.5 \mathrm{~m}$ were determined (Fig. 2):

- I: geometric 1.2-2.4 m; working 1.4-2.3 m,

- II: geometric 1.5-3.5 m; working 1.7-3.4 m,

- III: geometric 1.9-4.1 m; working 2.1-4.0 m,

- IV: geometric above $4.1 \mathrm{~m}$, working above $4.0 \mathrm{~m}$, where a pitch of $1.75 \mathrm{~m}$ is recommended to ensure the stability of the support.

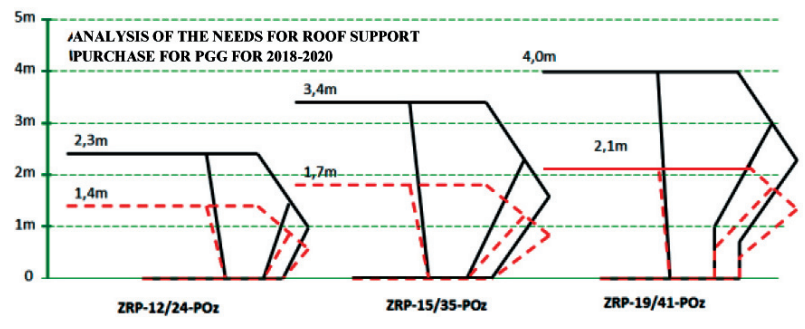

Fig. 2. Operating scope chart, supply for 2018-2020

The simplification of the components of a powered roof support and their unification is the next step in the standardization process. After completion of the already-started process, Polska Grupa Górnicza will be able to obtain a whole range of measurable benefits, such as:

1) increased work safety for miners:

- the structures will become repetitive, known to miners,

- equipment training will be easier and faster,

- good knowledge of a given structure directly reduces the risk of an accident resulting from poor knowledge about a given structure;

2) simplification of the structure - standardization:

- fewer technical solutions,

- optimal selection of component construction,

- interchangeability of basic elements, such as canopies and floor bases, auxiliary cylinders for all three types of newly designed roof supports;

3) improvement of purchase procedures of construction elements, power and control hydraulics;

4) significantly increase the possibility of using roof supports in other mines/longwalls;

5) basic reduction of costs related to renovation, modernization, and production of new support;

6) increased production capacity.

In Zakład Remontowo-Produkcyjny, Polska Grupa Górnicza, an algorithm of actions was developed to improve the investment process in the scope of servicing mines with the required types of powered roof supports (Fig. 3). The improvement of the efficiency of the repairs, modernization, and production of the new roof supports is based primarily on the process of aggregation of the components. Figure 4 presents ex- 
amples of the possibilities of using standardized components to adapt the roof supports to the individual needs of the mines on the example of a prototype type ZRP-15/35-POz roof support. On the basis of the at-

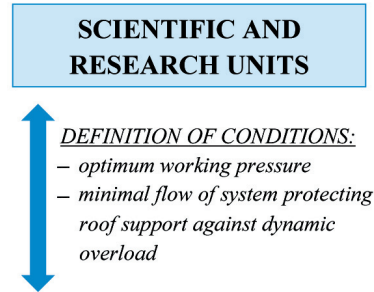

tached example, the principle of aggregation is clarified in which a given roof support can be configured depending on the requirements of the mine and the specific conditions of the extraction longwall.

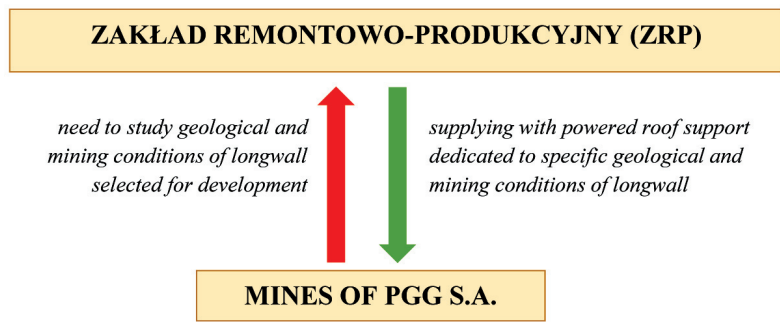

Fig. 3. Algorithm developed by Zakład Remontowo-Produkcyjny

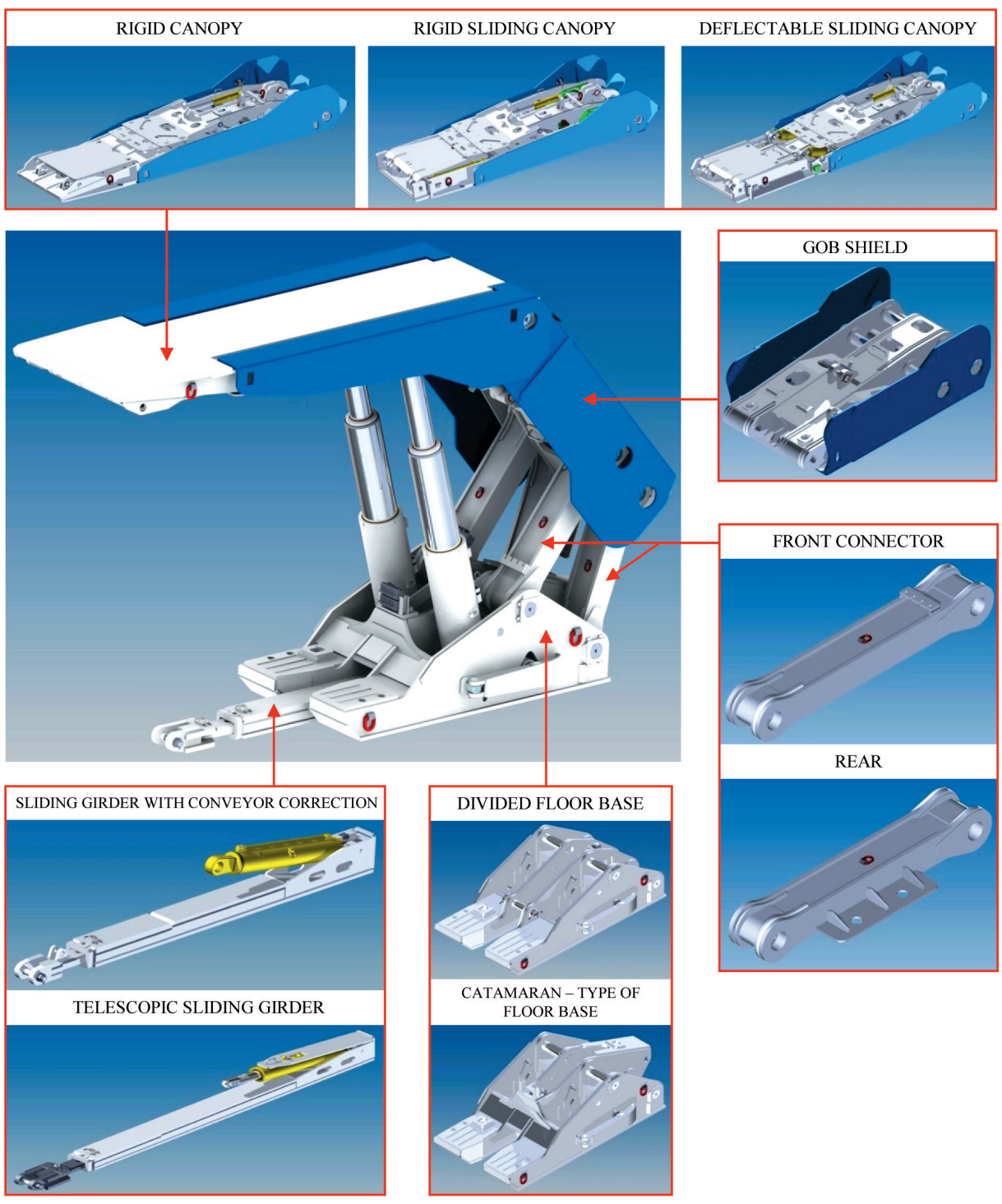

Fig. 4. Principle of aggregation - configuration of powered roof supports components 
The roof support can be configured from standardized elements (which are repeatable and fully meet safety and technical requirements and, to a significant extent, reduce production costs). The introduction of aggregation allows for the use of the same canopy or floor base for both the medium and high roof support produced, for example. It is also possible to use a canopy in various construction variants (rigid, rigid sliding, or deflectable sliding) in one support. Aggregation of the power hydraulic elements (standardization of actuators: wall face shields, transitions shields, correction of side shields of canopy and shield support, section shifters) as well as the control gear will enable the unification of the whole range of solutions and increase the production and purchase capacities and reduce costs.

\section{CONCLUSION}

Polska Grupa Górnicza implements the standardization process for powered roof supports. It is a difficult and demanding plan that will help bring tangible benefits. The risk of mining tremors is a significant natural threat to which the produced and modernized roof support should be adapted. For this purpose, activities were undertaken by Zakład Remontowo-Produkcyjny to obtain a high degree of safety of powered roof supports by means of technical and organizational measures as well as the method of production. Changes in Polish mining and the constantly deteriorating conditions for selecting coal deposits require the consistent implementation of rational solutions. The aggregation of the components of powered roof supports is constantly being developed and improved by Zakład Remontowo-Produkcyjny in close cooperation with scientific institutions; i.e., the Central Mining Institute and research laboratories. The purpose of the activities undertaken by Zakład Remontowo-Produkcyjny, PGG, is primarily to improve the safety of the work in underground longwall excavations while at the same time streamlining costs.

\section{References}

[1] Doległo L., Gil J., Kubiesa R., Stoiński K.: Układ sterowania stojakiem hydraulicznym typu ZRP dla potrzeb zmechanizowanych obudów ścianowych Kompanii Weglowej SA, XX Międzynarodowa Konferencja “Trwałość elementów i węzłów konstrukcyjnych maszyn górniczych" - TEMAG 2012, Politechnika Śląska, Gliwice.
[2] Gil J., Stoiński K.: Bezpieczeństwo zmechanizowanych obudów w systemach ścianowych, VI Międzynarodowa Konferencja Techniki Urabiania TUR 2013, Akademia Górniczo-Hutnicza, Kraków.

[3] Stoiński K.: Obudowy górnicze w warunkach zagrożenia wstrzasami górotworu, Główny Instytut Górnictwa, Katowice 2000.

[4] Dyrektywa 2006/42/WE Parlamentu Europejskie i Rady z dnia 17 maja 2006 r. w sprawie maszyn, zmieniajaca dyrektywe 95/16/WE, Dziennik Urzędowy Unii Europejskiej L157/24.

[5] PN-EN 1804-1+A1:2011: Maszyny dla górnictwa podziemnego - Wymagania bezpieczeństwa dla obudowy zmechanizowanej-czéść 1: Sekcje obudowy i wymagania ogólne.

[6] PN-EN 1804-2+A1:2012: Maszyny dla górnictwa podziemnego - Wymagania bezpieczeństwa dla obudowy zmechanizowanej-Część 2: Stojaki i pozostałe siłowniki.

[7] PN-EN 1804-3+A1:2012: Maszyny dla górnictwa podziemnego - Wymagania bezpieczeństwa dla obudowy zmechanizowanej-Część 3: Hydrauliczne układy sterowania.

[8] Rozporządzenie Ministra Energii z dnia 23 listopada 2016 r. w sprawie szczegółowych wymagań dotyczacych prowadzenia ruchu podziemnych zakładów górniczych, Dz.U. 2017, poz. 1118.

[9] Stoiński K., Gil J., Żak A., Karczewski T.: Zmechanizowane obudowy ścianowe - doświadczenia projektowe i produkcyjne PGG Sp. z o.o. oddziat Zakład Remontowo-Produkcyjny w Bieruniu, IV Polski Kongres Górniczy, Akademia Górniczo-Hutnicza, Kraków 2017.

[10] Gil J., Kubiesa R., Stoiński K.: Identyfikacja uszkodzeń hydrauliki sterowniczej zmechanizowanej obudowy ścianowej, XX Ogólnopolska Konferencja Nauk.-Tech. CYLINDER 2010 nt. Badanie, konstrukcja, wytwarzanie i eksploatacja układów hydraulicznych, Gliwice, KOMAG.

[11] Szurgacz D.: Sposób dostosowania obudowy ścianowej do warunków obciążeń dynamicznych, Przegląd Górniczy 2016, 7: 57-62.

[12] Stoiński K., Gil J.: Procedura optymalizacji upodatnienia zmechanizowanej obudowy ścianowej na przykładzie KW-12/ 25-ZRP, in: Mechanizacja, automatyzacja i robotyzacja w górnictwie, t. 1: Wybrane problemy górnictwa podziemnego, red. K. Kotwica, Lędziny - Kraków, Centrum Badań i Dozoru - Akademia Górniczo-Hutnicza, s. 76-83.

[13] Gil J., Labuzek M., Wencel H.: Innowacyjne rozwiąania eliminujace połaczenia spawane $i$ gwintowane $w$ siłownikach hydraulicznych stosowanych $w$ obudowach zmechanizowanych, XX Ogólnopolska Konferencja Nauk.-Tech. CYLINDER 2010 nt. Badanie, konstrukcja, wytwarzanie i eksploatacja układów hydraulicznych, Gliwice, KOMAG.

JAN GIL, Ph.D., Eng. MICHA屯 KOŁODZIEJ, M.Sc., Eng. Polska Grupa Górnicza S.A. Oddziat Zaktad Remontowo-Produkcyjny ul. Granitowa 132, 43-155 Bieruń, Poland zrp@pgg.pl

DAWID SZURGACZ, Ph.D., Eng. Polska Grupa Górnicza S.A. KWK ROW Ruch Chwatowice ul. Przewozowa 4, 44-206 Rybnik, Poland

KAZIMIERZ STOIŃSKI, prof. Gtówny Instytut Górnictwa pl. Gwarków 1, 40-166 Katowice, Poland 
$J A N$ GIL

MICHAE KOEODZIEJ

DAWID SZURGACZ

KAZIMIERZ STOIŃSKI

\title{
Wprowadzenie standaryzacji zmechanizowanych obudów ścianowych w celu zwiększenia efektywności produkcyjnej w Polskiej Grupie Górniczej S.A.
}

\begin{abstract}
Układy Wprowadzenie standaryzacji zmechanizowanych obudów ścianowych jest kluczowym punktem zwiększenia efektywności produkcyjnej w kopalniach Polskiej Grupy Górniczej S.A. Wprowadzone zmiany zwiększa bezpieczeństwo pracy górników, a także wptyna na wyniki ekonomiczne zwiazane z prowadzona eksploatacja wegla. Gtównym celem standaryzacji jest usystematyzowanie rozwiazań konstrukcyjnych obudów w zakresie hydrauliki sitowej $i$ sterowniczej, przy uwzględnieniu wszystkich warunków technicznych, jakie musza spetniać obudowy zmechanizowane pracujące w podziemnych zakładach górniczych zagrożonych wstrzasami górotworu. $W$ artykule przedstawiono sposób standaryzacji zmechanizowanych obudów ścianowych, remontowanych, modernizowanych oraz produkowanych przez Zakład Remontowo-Produkcyjny w ramach Polskiej Grupy Górniczej S.A.
\end{abstract}

Słowa kluczowe: standaryzacja, zmechanizowane obudowy ścianowe, zwiększenie efektywności produkcyjnej

\section{WPROWADZENIE}

Polska Grupa Górnicza S.A. aktualnie prowadzi eksploatację w około pięćdziesięciu ścianach w ośmiu kopalniach. Średnia głębokość eksploatacji to 710 metrów $\mathrm{z}$ tendencją wzrastającą. Zagrożenia naturalne stanowią głównie: wstrząsy górotworu, metan i w mniejszym stopniu woda. Eksploatację prowadzi się wyłącznie systemami ścianowymi na zawał, z wykorzystaniem kombajnu jako maszyny urabiającej [1,2]. Miąższość wybieranych ścian to około 2,6 m. Wydobycie roczne w PGG to około $30 \mathrm{mln}$ ton, średnio na dobę 82 tys. ton. W zdecydowanej większości stosowane są obudowy podporowo-osłonowe, dwustojakowe. Ponad 60\% ścian eksploatacyjnych prowadzonych jest w warunkach zagrożenia wstrząsami górotworu, stopień zagrożenia wstrząsami górotworu oceniony na podstawie współczynnika $n_{\mathrm{tz}}$ zawiera się w przedziale 1,1-1,4 [1-3]. Zapewnienie odpowiedniego utrzymania stropu opisanego wskaźnikiem $g$ zawiera się w przedziale 0,7 do ponad 1,2, co świadczy o braku optymalizacji podporności obudów w odniesieniu do rzeczywistych potrzeb. W jednej ścianie to znajduje się od dwóch do pięciu typów obudów. Podstawowe ciśnienie zasilania to $25 \mathrm{MPa}$. Najczęściej stosuje się sterowanie przyległe typu RB, w nielicznych przypadkach sterowanie pilotowe. Natomiast elektrosterowanie nie jest stosowane. W pojedynczych przypadkach korzysta się z systemów elektronicznego nadzoru ciśnień roboczych. W eksploatacji aktualnie zarejestrowanych jest około 200 odmian obudów ścianowych, głównie typu podporowo-osłonowego ze stojakami różnej konstrukcji (średnice cylindrów, długości). Przykładowy wykaz stanu posiadania obudów różnych typów wybranej kopalni PGG prezentuje tabela 1.

Znaczna liczba ścian wyposażona jest w kilka typów sekcji różniących się często geometrią i podpornością. $\mathrm{W}$ eksploatowanych obudowach $\mathrm{z}$ różnych względów (finansowych, organizacyjnych, dostępności oryginalnych części zamiennych) obserwuje się 
niekiedy stosowanie „substytutów wątpliwej jakości” zamiast oryginalnych. Utrudnia to w znaczącym stopniu eksploatację obudów i ich naprawy oraz ustalenie rzeczywistych przyczyn nieprawidłowego działania. Warto również zwrócić uwagę na to, że większość zmechanizowanych obudów pracujących w kopalniach PGG ma średnio dwadzieścia lat, a w eksploatacji nadal znajdują się obudowy o konstrukcji nawet sprzed trzydziestu lat. W tabeli 2 przedstawiono liczbę sekcji pracujących w PGG w zależności od roku produkcji.

Tabela 1

Przykładowy stan posiadania różnych typów obudów z wybranej kopalni

\begin{tabular}{|l|c|}
\hline \multicolumn{1}{|c|}{ Typ obudowy zmechanizowanej } & $\begin{array}{c}\text { Zakres wysokości } \\
\text { roboczej sekcji [m] }\end{array}$ \\
\hline Fazos 08/22 2x2690 & $1,0-2,1$ \\
\hline Fazos 08/22 2x2690-1 & $1,0-2,1$ \\
\hline KW 09/26 POz/ZRP w. III & $1,5-2,5$ \\
\hline KW 09/26 POz/ZRP/BSN w. III & $1,5-2,5$ \\
\hline Fazos 16/37 POz & $1,7-3,7$ \\
\hline Fazos 16/37 POz/BSN & $1,7-3,7$ \\
\hline KW 16/37 POz/ZRP & $1,8-3,6$ \\
\hline KW 16/37 POz/ZRP/BSN & $1,8-3,6$ \\
\hline Tagor 18/36 POz & $2,0-3,5$ \\
\hline Tagor 18/36 POz/S & $2,0-3,5$ \\
\hline Fazos 19/35 OzM5 & $1,9-3,4$ \\
\hline KW 20/36 POz/ZRP & $2,2-3,5$ \\
\hline KW 20/36 POz/ZRP/BSN & $2,2-3,5$ \\
\hline KW 20/36 POzW1/ZRP & $2,2-3,5$ \\
\hline KW 14/28 POz/ZRP & $1,5-2,7$ \\
\hline KW 14/28 POz/ZRP/BSN & $1,5-2,7$ \\
\hline Fazos 15/31 OzM5 & $1,7-3,0$ \\
\hline BW 20/36 OzMR2 & $2,5-3,5$ \\
\hline BW 17/43POz & $2,0-3,6$ \\
\hline
\end{tabular}

Tabela 2

Zestawienie liczby obudów pracujących w PGG z podziałem na rok produkcji

\begin{tabular}{|l|c|}
\hline \multicolumn{1}{|c|}{ Rok produkcji } & Liczba obudów [szt.] \\
\hline Do 1980 r. & 434 \\
\hline 1981-2000 & 6620 \\
\hline 2001-2016 & 8056 \\
\hline
\end{tabular}

Różnorodność odmian oraz rozwiązań technicznych komplikuje wszelkie naprawy i możliwości wykorzystania pracujących obudów w innych ścianach.
Wszystkie obudowy, niezależnie od sposobu wprowadzenia ich na rynek, w przypadku stosowania w warunkach zagrożenia wstrząsami górotworu podlegają dodatkowej ocenie upodatnienia najczęściej przez jednostkę naukowo-badawczą. W tabeli 3 przedstawiono liczbę sekcji obudów w PGG w zależności od sposobu wprowadzania na rynek.

Tabela 3

Liczba sekcji w PGG w zależności od sposobu wprowadzenia na rynek

\begin{tabular}{|c|c|c|}
\hline $\begin{array}{c}\text { Rok } \\
\text { produkcji }\end{array}$ & $\begin{array}{c}\text { Liczba } \\
\text { obudów [szt.] }\end{array}$ & $\begin{array}{c}\text { Podstawa prawna } \\
\text { wprowadzenia na rynek }\end{array}$ \\
\hline Do 2004 r. & 7443 & dopuszczenie wydane przez WUG \\
\hline Od 2004 r. & 7667 & certyfikat badania typu WE \\
\hline
\end{tabular}

Aktualnie obudowa jest wprowadzana na rynek zgodnie $\mathrm{z}$ wymaganiami bezpieczeństwa określonymi w dyrektywach Parlamentu Europejskiego i zharmonizowanymi z nimi polskimi normami. Podstawowym dokumentem jest dyrektywa maszynowa [4] oraz zharmonizowane z nią polskie normy z serii PN-EN 1804 [5-7]. $\mathrm{Z}$ uwagi na to, że normy z serii PN-EN 1804 ujmują zapis wyłączający ich obowiązywanie w odniesieniu do przypadku zagrożenia wstrząsami górotworu, obudowę należy przystosować w drodze „upodatnienia” do przejmowania obciążeń dynamicznych na mocy Rozporzadzenia Ministra Energii z dnia 23 listopada 2016 r. $w$ sprawie szczegółowych wymagań dotyczacych prowadzenia ruchu podziemnych zakładów górniczych (obowiązującego od 1 lipca 2017 r.) [8].

Nowe rozporządzenie Ministra Energii, w odróżnieniu od wcześniej obowiązującego Rozporzadzenia Ministra Gospodarki $z$ dnia 28 czerwca 2002 r. $w$ sprawie bezpieczeństwa i higieny pracy, prowadzenia ruchu oraz specjalistycznego zabezpieczenia przeciwpożarowego $w$ podziemnych zakładach górniczych (obowiązującego do 1 lipca 2017 r.) nie ujmuje wymogu oceny możliwości współpracy różnych typów obudowy w jednej ścianie. Oznacza to, że w świetle aktualnie obowiązujących aktów prawnych ocena możliwości współpracy kilku obudów w jednej ścianie jest nieobowiązkowa i spoczywa wyłącznie na kierowniku działu górniczego, który może wspomagać się opinią powołanych zespołów opiniodawczych. Stosowanie kilku typów obudowy zmechanizowanej w jednej ścianie stwarza wiele problemów. Z przeprowadzonej analizy [9] wynika, że ważnym etapem w procesie dostosowywania obudowy do panujących w danym wyrobisku warunków geologiczno-górniczych jest dobór jej układu podpornościowego [10, 11], wynikający ściśle 
z oceny wskaźnika utrzymania stropu $g$. Dla bezpiecznej i efektywnej pracy kompleksu ścianowego zaleca się dalszą współpracę z Głównym Instytutem Górnictwa i nieodchodzenie od praktyki wspomagania się wskaźnikiem nośności stropu $g$ przy doborze obudowy do rzeczywistych warunków eksploatacyjnych. W niniejszym opracowaniu przedstawiono proces standaryzacji zmechanizowanych obudów ścianowych zarówno remontowanych, jak i produkowanych w ramach PGG S.A.

\section{ZASADY EKSPLOATACJI OBUDÓW ŚCIANOWYCH}

Perspektywa sprostania wymaganiom rynku wymusza zdecydowaną racjonalizację kosztów wydobycia węgla w drodze poprawy organizacji, zatrudnienia oraz stopnia wykorzystania maszyn, co powinno prowadzić do zwiększenia wydobycia dobowego ze ściany. Tendencję taką należy utrzymać przy pogarszających się warunkach górniczych oraz silnej konkurencji zewnętrznej. Korzyści płynące z powyższego procesu to: zapewnienie bezpieczeństwa pracy kompleksu ścianowego, zapewnienie funkcjonalności przy minimalizacji kosztów zakupu i eksploatacji.

Standaryzację zainicjowano dziesięć lat temu w Zakładzie Remontowo-Produkcyjnym, będącym oddziałem Polskiej Grupy Górniczej.

Nieodzowna była współpraca $\mathrm{z}$ jednostkami naukowo-badawczymi (m.in. z Głównym Instytutem Górnictwa oraz z Instytutem Techniki Górniczej KOMAG), jak i jednostkami kooperującymi. Coraz trudniejsze warunki górniczo-geologiczne przyczyniają się do wzrostu zagrożenia wstrząsami górotworu, narzucają precyzyjne warunki techniczne, jakie muszą spełniać obudowy zmechanizowane, oraz wskazują na konieczność ujednolicenia konstrukcji obudowy.

Na podstawie analizy tego stanu oraz przewidywanych potrzeb na najbliższe lata określono najważniejsze kierunki działania w zakresie standaryzacji konstrukcji zmechanizowanych obudów ścianowych [12]. Ustalenie podstawowych kierunków standaryzacji konstrukcji obudów pozwoliło zoptymalizować gospodarkę obudowami, w pełni wykorzystać posiadany park obudów zmechanizowanych i potencjał produkcyjny Zakładu Remontowo-Produkcyjnego.

Zasadniczo standaryzacja objęła trzy główne składowe obudowy:

- konstrukcję sekcji,

- hydraulikę siłową,

- hydraulikę sterowniczą.
Odnośnie do przyjętej koncepcji podjęto działania w zakresie:

1) konstrukcji sekcji, na którą składają się następujące etapy:

- dostosowanie wysokości roboczej obudów zmechanizowanych do aktualnych potrzeb,

- zwiększenie podporności obudów przy jednoczesnym wzmocnieniu konstrukcji obudów posiadanych przez PGG,

- wprowadzenie procedur własnych - Zakład Remontowo-Produkcyjny zaostrzył narzucane przez normy dopuszczalne współczynniki bezpieczeństwa odnośnie do obciążenia gniazd stojakowych (wprowadzenie współczynnika 2 zamiast wymaganego 1,5) [13],

- wprowadzenie do obudów na wniosek przedstawicieli kopalń udogodnień, które ułatwiają eksploatację i naprawy,

- wprowadzenie i zastosowanie dla różnych typów obudów tych samych siłowników pomocniczych (siłownik osłony czoła ściany, osłony przejścia, siłownik korekcji osłon bocznych);

2) hydrauliki siłowej, przy czym:

- stojaki ograniczono do jednego typu, o budowie dwuteleskopowej z zaworem dennym, ze średnicami I stopnia:

- 0,21 m - KW-08/22-POz/ZRP, KW-09/26-POz/ ZRP,

- 0,25 m - KW-14/28-POz/ZRP, KW-18/34-POz/ ZRP, KW-20/36-POz/ZRP, KW-17/43-POz/ ZRP,

-0,32 m - KW-16/37-POz/ZRP;

- stojaki hydrauliczne wyposażane są w przyłącza stojakowe typu ZRP:

- wielkość I: DN12/DN12 - minimalne przepływy dla $60 \mathrm{MPa} 450 \mathrm{l} / \mathrm{min}$ przy stratach przepływu na poziomie $15 \%$ dla stojaka o średnicy I stopnia $0,21 \mathrm{~m}$,

- wielkość II: DN19/DN12 - minimalne przepływy dla $60 \mathrm{MPa} 650 \mathrm{l} / \mathrm{min}$ przy stratach przepływu na poziomie $15 \%$ dla stojaka o średnicy I stopnia $0,25 \mathrm{~m}$ i $0,32 \mathrm{~m}$.

3) hydrauliki sterowniczej - wprowadzenie procedury doboru zabezpieczenia sekcji obudowy zmechanizowanej przed przeciążeniami dynamicznymi na podstawie metody wyznaczania przepływu wypadkowego układu przyłącze-zawór (rys. 1). W tym celu Zakład Remontowo-Produkcyjny opracował szczegółowe wymagania zakupu zaworów ograniczających ciśnienie - zaworów upustowych. 


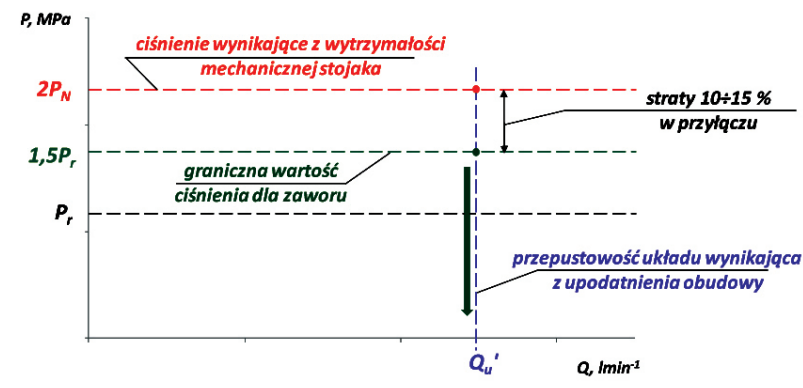

Rys. 1. Metoda wyznaczania przeptywu wypadkowego układu przyłącze-zawór

\section{KIERUNEK STANDARYZACJI}

Sekcja zmechanizowanej obudowy ścianowej zgodnie $\mathrm{z}$ dyrektywą maszynową jest maszyną składającą się z konstrukcji, hydrauliki siłowej oraz sterującej i jako całość powinna być wprowadzona na rynek oraz użytkowana w postaci niezmienionej w całym okresie działania maszyny. Jest to niezwykle istotne ze względów bezpieczeństwa, technicznych oraz poniesionych kosztów. Odstępstwo od wymienionych zasad skutkuje radykalnym wzrostem ryzyka awarii, co przekłada się na pogorszenie bezpieczeństwa pracy. Kwestią pochodną, również korzystną, jest ujednolicenie zapotrzebowania na elementy zakupowe, uproszczenie prac eksploatacyjnych i wszelkiego rodzaju napraw.

Wychodząc naprzeciw tym wymaganiom, PGG S.A. postanowiła zabezpieczyć najbliższe własne potrzeby w zakresie uzbrojenia ścian w obudowy zmechanizowane pozyskane na podstawie własnej dokumentacji, uwzględniającej standaryzację i agregacyjny system zakupu. W tym celu dokonano analizy potrzeb opartej na zakresie pracy sekcji obudów do 2020 r. (tab. 4).

Tabela 4

Zestawienie potrzeb w zakresie sekcji obudów zmechanizowanych na lata 2018-2020

\begin{tabular}{|c|c|}
\hline Zakres pracy & Liczba sekcji \\
\hline $1,0-2,5$ & 178 \\
\hline $1,8-3,3$ & 425 \\
\hline $2,0-4,0$ & 318 \\
\hline $2,6-4,6$ & 121 \\
\hline
\end{tabular}

Mając na uwadze powyższe potrzeby oraz zoptymalizowanie zakresy robocze dla nowo projektowanych obudów w Zakładzie Remontowo-Produkcyjnym podjęto prace projektowe celem opracowania nowych typów obudów. Określono trzy zasadnicze typy obudowy podporowo-osłonowej opartej na podziałce $1,5 \mathrm{~m}$ (rys. 2):

- I: geometryczna 1,2-2,4 m; robocza 1,4-2,3 m;

- II: geometryczna 1,5-3,5 m; robocza 1,7-3,4 m;

- III: geometryczna 1,9-4,1 m; robocza 2,1-4,0 m;

- IV: geometryczna powyżej 4,1 m; robocza powyżej 4,0 $\mathrm{m}$ - gdzie zalecana jest podziałka $1,75 \mathrm{~m}$, aby zapewnić stateczność obudowy.

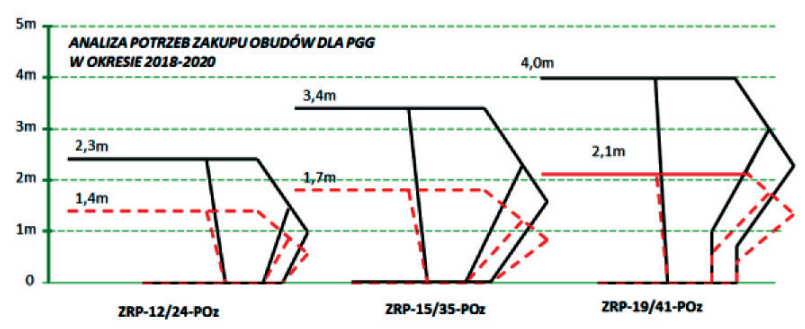

Rys. 2. Zakres roboczy obudów - zaopatrzenie w latach 2018-2020

Uproszczenie składowych podzespołów obudowy ścianowej i ich unifikacja jest następnym krokiem w procesie standaryzacji. Polska Grupa Górnicza po ukończeniu rozpoczętego już procesu będzie w stanie uzyskać całą gamę wymiernych korzyści, takich jak:

1) zwiększenie bezpieczeństwa pracy górników:

- konstrukcje staną się powtarzalne, znane górnikom,

- szkolenie w zakresie obsługi sprzętu stanie się prostsze i szybsze,

- dobra znajomość danej konstrukcji bezpośrednio skutkuje zmniejszeniem ryzyka wypadku będącego wynikiem słabej wiedzy o danej konstrukcji;

2) uproszczenie konstrukcji - standaryzacja:

- mniejsza liczba rozwiązań technicznych,

- optymalny dobór konstrukcji podzespołów,

- zamienność elementów podstawowych np. stropnic i spagnic, siłowników pomocniczych dla wszystkich trzech typów nowo projektowanych obudów;

3) usprawnienie procedur zakupowych elementów konstrukcji, hydrauliki siłowej i sterowniczej;

4) znaczne zwiększenie możliwości wykorzystania obudów w innych kopalniach/ ścianach;

5) zasadnicze zmniejszenie kosztów związanych z remontami, modernizacją jak i produkcją nowych obudów;

6) zwiększenie możliwości produkcyjnych.

W Zakładzie Remontowo-Produkcyjnym Polskiej Grupy Górniczej opracowano algorytm działań mających na celu usprawnienie procesu inwestycyjnego, w zakresie obsłużenia kopalń w wymagane rodzaje 
obudów zmechanizowanych (rys. 3). Poprawa efektywności remontów, modernizacji i produkcji nowych obudów oparta jest przede wszystkim na procesie agregacji podzespołów obudów. Na rysunku 4 przed- stawiono przykładowe możliwości wykorzystania standaryzowanych podzespołów dla przystosowania obudowy do indywidualnych potrzeb kopalń na przykładzie prototypowej obudowy typu ZRP-15/35-POz.

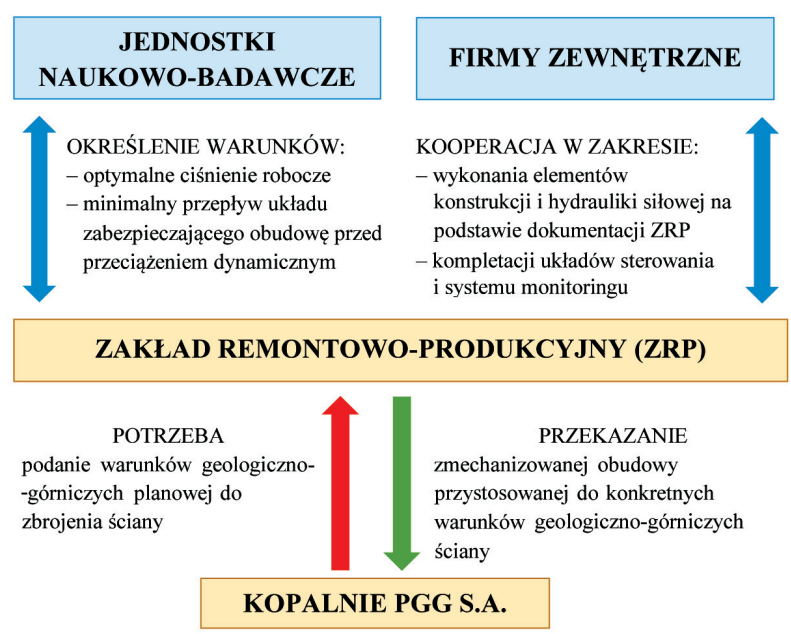

Rys. 3. Algorytm działań Zaktadu Remontowo-Produkcyjnego

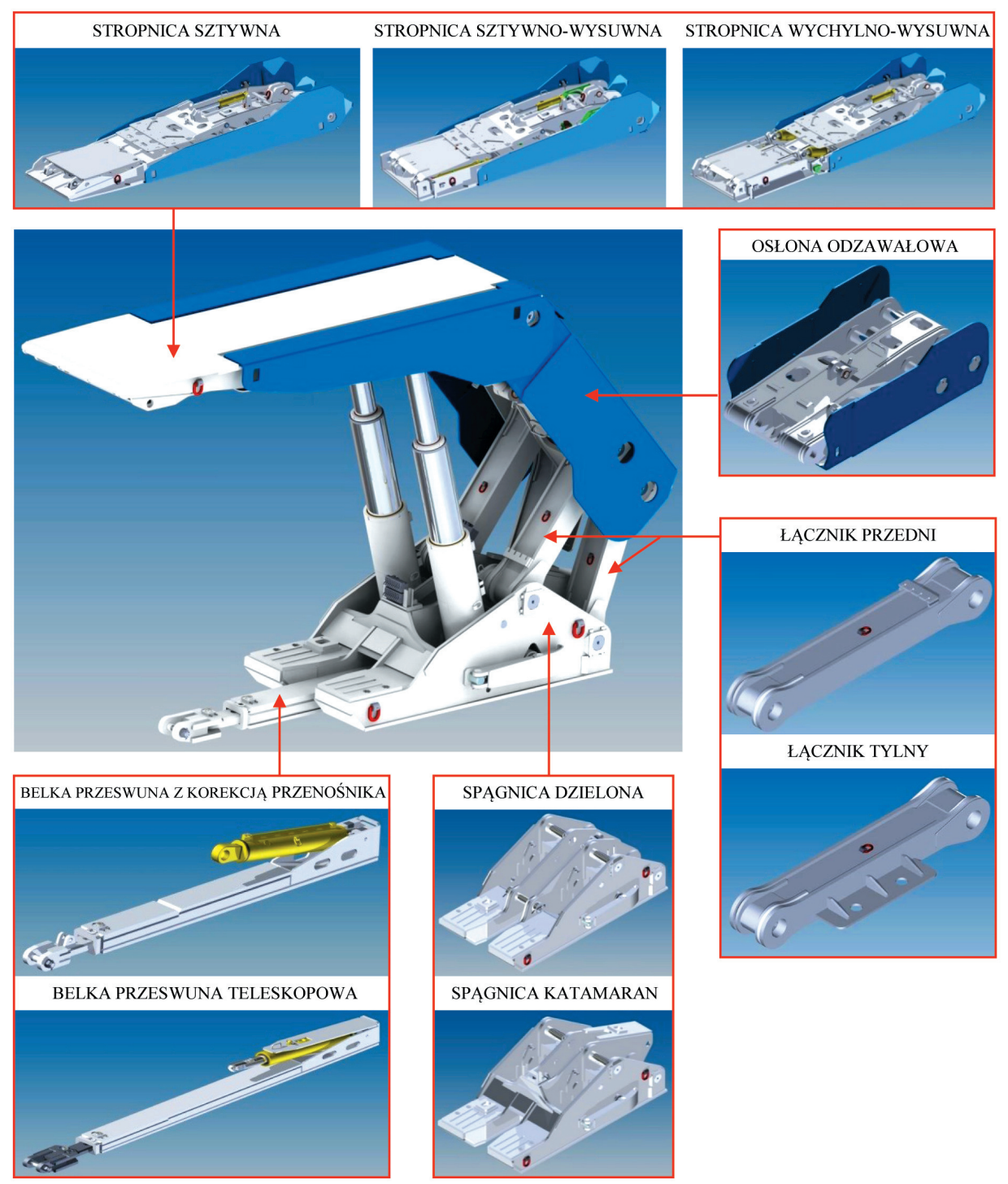

Rys. 4. Zasada agregacji - konfigurowanie podzespołów zmechanizowanej obudowy ścianowej 
$\mathrm{Na}$ podstawie załączonego przykładu wyjaśniono zasadę agregacji, w której daną obudowę można skonfigurować w zależności od wymagań kopalni i określonych warunków ściany wydobywczej. Obudowę można konfigurować ze standaryzowanych elementów, które są powtarzalne i w pełni spełniają wymogi techniczne, bezpieczeństwa oraz w znacznym stopniu redukują koszty produkcji. Wprowadzenie agregacji umożliwia np. zastosowanie tej samej stropnicy czy spąnicy zarówno do produkowanej obudowy średniej oraz wysokiej. Możliwe jest również użycie np. stropnicy w różnych wariantach konstrukcyjnych (stropnica sztywna, sztywno-wysuwna czy wychylno-wysuwna) w ramach jednej obudowy. Agregacja elementów hydrauliki siłowej (standaryzacja siłowników: osłony czoła ściany, osłony pola przejścia, korekcji osłon bocznych stropnicy oraz osłony odzawałowej, przesuwniki sekcji) i sterującej umożliwi ujednolicenie całej gamy rozwiązań oraz zwiększenie możliwości produkcyjnych, zakupowych i ograniczenie kosztów.

\section{PODSUMOWANIE}

Polska Grupa Górnicza wdraża proces standaryzacji obudów zmechanizowanych. Jest to trudny i wymagający dużego zaangażowania plan, który przyniesie wymierne korzyści. Zagrożenie wstrząsami górotworu stanowi istotne zagrożenie naturalne, do którego należy przystosować produkowane i modernizowane obudowy. W tym celu zostały podjęte przez Zakład Remontowo-Produkcyjny umożliwiające uzyskanie wysokiego stopnia bezpieczeństwa zmechanizowanych obudów ścianowych działania techniczne, organizacyjne oraz sposób prowadzenia produkcji. Zmieniające się polskie górnictwo, coraz trudniejsze warunki wybierania pokładów węgla, wymagają konsekwentnego wdrażania racjonalnych rozwiązań. Agregacja podzespołów składowych obudów zmechanizowanych jest cały czas rozwijana i udoskonalana przez Zakład RemontowoProdukcyjny PGG przy ścisłej współpracy z instytucjami naukowymi, tj. GIG-iem oraz laboratoriami badawczymi. Celem podjętych przez ZRP PGG działań jest przede wszystkim poprawa bezpieczeństwa pracy w podziemnych wyrobiskach ścianowych przy jednoczesnej racjonalizacji kosztów.

\section{Literatura}

[1] Doległo L., Gil J., Kubiesa R., Stoiński K.: Układ sterowania stojakiem hydraulicznym typu ZRP dla potrzeb zmechanizowanych obudów ścianowych Kompanii Węglowej SA, XX Międzynarodowa Konferencja „Trwałość elementów i węzłów konstrukcyjnych maszyn górniczych" - TEMAG 2012, Politechnika Śląska, Gliwice.
[2] Gil J., Stoiński K.: Bezpieczeństwo zmechanizowanych obudów $w$ systemach ścianowych, VI Międzynarodowa Konferencja Techniki Urabiania TUR 2013, Kraków, Akademia Górniczo-Hutnicza.

[3] Stoiński K.: Obudowy górnicze w warunkach zagrożenia wstrząsami górotworu, Główny Instytut Górnictwa, Katowice 2000.

[4] Dyrektywa 2006/42/WE Parlamentu Europejskie i Rady z dnia 17 maja 2006 r. w sprawie maszyn, zmieniajaca dyrektywe 95/16/WE, Dziennik Urzędowy Unii Europejskiej L157/24.

[5] PN-EN 1804-1+A1:2011: Maszyny dla górnictwa podziemnego - Wymagania bezpieczeństwa dla obudowy zmechanizowanej - część 1: Sekcje obudowy i wymagania ogólne.

[6] PN-EN 1804-2+A1:2012: Maszyny dla górnictwa podziemnego - Wymagania bezpieczeństwa dla obudowy zmechanizowanej-Część 2: Stojaki i pozostałe siłowniki.

[7] PN-EN 1804-3+A1:2012: Maszyny dla górnictwa podziemnego - Wymagania bezpieczeństwa dla obudowy zmechanizowanej-Część 3: Hydrauliczne układy sterowania.

[8] Rozporzadzenie Ministra Energii z dnia 23 listopada 2016 r. w sprawie szczegółowych wymagań dotyczacych prowadzenia ruchu podziemnych zakładów górniczych, Dz.U. z 2017 r., poz. 1118.

[9] Stoiński K., Gil J., Żak A., Karczewski T.: Zmechanizowane obudowy ścianowe - doświadczenia projektowe i produkcyjne PGG Sp. z o.o. oddziat Zakład Remontowo-Produkcyjny w Bieruniu, IV Polski Kongres Górniczy, Akademia Górniczo-Hutnicza, Kraków 2017.

[10] Gil J., Kubiesa R., Stoiński K.: Identyfikacja uszkodzeń hydrauliki sterowniczej zmechanizowanej obudowy ścianowej, XX Ogólnopolska Konferencja Naukowo-Techniczna CYLINDER 2010 „Badanie, konstrukcja, wytwarzanie i eksploatacja układów hydraulicznych”, KOMAG, Gliwice 2010.

[11] Szurgacz D.: Sposób dostosowania obudowy ścianowej do warunków obciążeń dynamicznych, „Przegląd Górniczy” 2016, 7: $57-62$.

[12] Stoiński K., Gil J.: Procedura optymalizacji upodatnienia zmechanizowanej obudowy ścianowej na przykładzie KW-12/25-ZRP, w: Mechanizacja, Automatyzacja i Robotyzacja w Górnictwie, t. 1: Wybrane problemy górnictwa podziemnego, red. K. Kotwica, Centrum Badań i Dozoru - Akademia Górniczo-Hutnicza, Lędziny - Kraków, s. 76-83.

[13] Gil J., Łabuzek M., Wencel H.: Innowacyjne rozwiazania eliminujace połaczenia spawane $i$ gwintowane $w$ siłownikach hydraulicznych stosowanych $w$ obudowach zmechanizowanych, XX Ogólnopolska Konferencja Naukowo-Techniczna CYLINDER 2010 „Badanie, konstrukcja, wytwarzanie i eksploatacja układów hydraulicznych”, KOMAG, Gliwice 2010.

dr inż. JAN GIL

mgr inż. MICHA屯 KOŁODZIEJ

Polska Grupa Górnicza S.A.

Oddziat Zakład Remontowo-Produkcyjny ul. Granitowa 132, 43-155 Bieruń

zrp@pgg.pl

dr inż. DAWID SZURGACZ

Polska Grupa Górnicza S.A.

KWK ROW Ruch Chwałowice ul. Przewozowa 4, 44-206 Rybnik

prof. dr hab. inż. KAZIMIERZ STOIŃSKI

Gtówny Instytut Górnictwa

pl. Gwarków 1, 40-166 Katowice 